\title{
UPAYA PENINGKATAN HASIL BELAJAR BIOLOGI MELALUI MODE PEMBELAJARAN "ROAD BENIK" PADA SISWA SMP NEGERI 1 TAKERAN KELAS IX B SEMESTER I TAHUN PELAJARAN 2013/2014
}

\author{
Anik Rofaida Lestari \\ SMP 2 Takeran, Kab. Magetan
}

\begin{abstract}
ABSTRAK
Metode pembelajaran road benik adalah suatu metode pembelajaran dimana siswa mempelajari fakta, konsep atau prinsip tertentu melalui permainan yang dikompetisikan. Berdasarkan observasi awal yang dilakukan peneliti di kelas IX B SMPN 1 Takeran, dapat diketahui bahwa pengajaran oleh guru biasanya dilakukan dengan ceramah, diskusi, tanya jawab dan menggunakan alat peraga. Cara pengajaran seperti itu akan mengakibatkan siswa menjadi bosan sehingga motivasi anak rendah dan hasil belajar siswa menurun, oleh sebab itu peneliti menerapkan metode pembelajaran road benik dalam upaya meningkatkan motivasi dan hasil belajar siswa SMPN 1 Takeran kelas IX B. Subyek penelitian adalah siswa kelas IX B SMPN 1 Takeran semester ganjil tahun ajaran 2013/ 2014. Metode Penelitian yang digunakan adalah metode Penelitian Tindakan Kelas yang terdiri dari dua siklus. Instrumen penelitian berupa soal tes prestasi siswa,angket motivasi siswa, lembar observasi kreatifitas belajar siswa, dan lembar observasi kegiatan guru. Analisis hasil penelitian dideskripsikan dengan menggunakan tehnik persentase. Berdasarkan hasil penelitian, maka didapatkan hasil bahwa penerapan model pembelajaran road benik dapat meningkatkan hasil belajar siswa. Hasil perolehan yang membuktikan hal tersebut adalah terjadinya peningkatkan hasil prestasi belajar siswa dari siklus I $70,00 \%$ ke siklus II 85,00 \% keberhasilan dalam motivasi siswa terhadap pembelajaran dengan model road benik $05,00 \%$ respon cukup, $65,00 \%$ respon baik, 30,00 \% respon sangat baik, Ini terlihat dari siswa sangat senang mengikuti pembelajaran dengan model road benik. Peningkatkan kreatifitas belajar siswa, dari siklus I 50,00 \% ke siklus II 70,00 \% dan peningkatan hasil kegiatan guru dari siklus I $28,80 \%$ ke siklus II $57,69 \%$.
\end{abstract}

Kata Kunci : Model Pembelajaran road benik, Hasil belajar

\section{PENDAHULUAN}

Berdasakan observasi yang dilakukan peneliti di lapangan dapat diketahui bahwa pengajaran di Kelas IX D SMP Negeri 1 Takeran, materi "Seleksi Alam" biasanya urutan penyajiannya dengan metode ceramah atau cerita, disertai dengan penggunaan alat peraga berupa kertas manila dan potongan kecil-kecil kertas berwarna warni yang di sebar di halaman berumput, kemudian dilanjutkan diskusi, serta tanya jawab.

Dengan teknis penyajian tersebut ada banyak siswa kurang terlibat dan kurang bisa memahami meskipun itu dibantu dengan alat peraga. Kelemahan pelaksanaan pembelajaran biologi dengan urutan tersebut adalah pembelajaran berpusat pada guru (teacher center) dan pada beberapa siswa saja sehingga ada beberapa siswa cenderung pasif. Selain itu jika kertas terlalu kecil susah dalam pengambilan apalagi jika rumput kondisi basah habis hujan. Hal tersebut ditunjukkan dengan perhatian beberapa siswa yang kurang, biasanya siswa cuek, ramai atau melakuakan hal-hal yang menurutnya mengasikkan, misalnya bermain sendiri saat kegiatan atau bahkan menggoda temannya, karena kurang dilibatkan dalam proses pembelajaran. Perolehan pengetahuan juga terbatas pada informasi yang diberikan oleh guru.Akibatnya kemampuan siswa dalam menerima dan memahami konsep pengetahuan masih kurang. Cara pengajaran seperti ini akan mengakibatan kebosanan dan kejenuhan pada siswa, khususnya siswa yang terbiasa aktif. Di samping itu motivasi dan 
minat belajar siswa berkurang, siswa menjadi malas akibatnya hasil belajar siswa rendah.

Hal ini senada dengan pernyataan Runtut Prih Utami (2006 : 1), bahwa "Pembelajaran model ceramah klasikal mempunyai banyak kelemahan, diantaranya peran guru dalam pembelajaran ini lebih dominan (teacher center), siswa cenderung pasif dan hanya menerima informasi”.Untuk mengatasi rendahnya hasil belajar siswa dan untuk meningkatkan keaktifan, kreativitas, serta motivasi siswa perlu dilakukan suatu inovasi dalam pembelajaran. Guru profesional dituntut dapat melakukan pembelajaran di dalam kelas dengan pola dan metode yang mampu membangkitkan motivasi dan kreativitas belajar siswa sehingga proses interaksi siswa dalam pembelajaran dapat meningkat. Inovasi pembelajaran dapat dilakukan melalui peningkatan dan perbaikan kualitas pembelajaran. Penggunaan metode pembelajaran yang sesuai merupakan salah satu alternatif untuk mengatasi masalah dalam proses kegiatan pembelajaran di atas. Pembelajaran dengan "metode road benik" merupakan salah satu alternatif inovasi pembelajaran yang memungkinkan siswa menggunakan segala aktivitasnya seperti bermain, berkompetisi, melakukan pengumpulan data, menganalisis data dan menarik kesimpulan. "Road benik" juga melatih siswa untuk jujur, obyektif, terbuka dan dapat menemukan konsep atau prinsip ilmiah. Belajar lebih dari sekedar mengingat. Hal ini senada dengan pendapat Thomas M. Duffy dan David H. Jonassen (1992 : 102), bahwa "Assumption of Constructivism.... Learning is active. Learning is an active process in which meaning is developed on the basis of experience."

Masing-masing model pembelajaran mempunyai kelemahan dan kelebihan, namun guru diharapkan untuk bisa meminimalisir kelemahan, di samping itu kelebihan yang ada pada model pembelajaran yang tepat akan memberikan nuansa, makna dan pemahaman siswa sehingga memperlancar dan mempercepat tercapainya tujuan pada suatu proses belajar mengajar. Berangkat dari pemikiran di atas, maka peneliti mengadakan penelitian mengenai Upaya Peningkatan Prestasi Belajar Biologi Pada Siswa SMP Negeri 1 Takeran Kelas IX D Melalui Model Pembelajaran "Road Benik"

\section{METODE PENELITIAN}

Subjek penelitian ini adalah siswa Kelas IX B Semester I di SMPN 1 Takeran Magetan Tahun Ajaran 2013 / 2014.Jumlah siswa kelas IX B adalah 20 siswa, yang terdiri dari 9 siswa putra dan 11 siswa putri. Penelitian yang digunakan adalah Penelitian Tindakan Kelas (PTK). Secara garis besar pelaksanaan Penelitian Tindakan Kelas dilakukan melalui siklus-siklus, dimana pada tiap siklus terdapat 4 tahap, yaitu: 1) Tahap Perencanaan (Planning), 2) Tahap Pelaksanaan (Acting), 3) Tahap Pengamatan (Observing), 4) Tahap Refleksi (Reflecting). (Suharsimi Arikunto, 2006:16)

\section{HASIL PENELITIAN}

Sebelum masuk ke siklus I kegiatan yang dilakukan adalah melakukan pengamatan pendahuluan untuk mengetahui kondisi awal siswa dan keadaan kelas

Tabel 1. Hasil Prestasi Belajar Siswa Siklus I

\begin{tabular}{cccccc}
\hline No & SKBM & Kriteria & Frekuensi & Prosentase (\%) & Keterangan \\
\hline 1 & 70 & $\square 70$ & 6 & $30,00 \%$ & Belum tuntas \\
\hline 2 & & $\square 70$ & 14 & $70,00 \%$ & Tuntas \\
\hline & Jumlah & & 20 & $100 \%$ & \\
\hline
\end{tabular}


Dari tabel 1 dapat diketahui bahwa dari 20 siswa, jumlah siswa yang belum tuntas belajar pada siklus I adalah 6 siswa, sedangkan jumlah siswa yang tuntas sebanyak 14 dengan persentase 70,00\%. Ketuntasan belajar siswa dilihat melalui SKBM yaitu yang mendapatkan nilai lebih dari atau sama dengan 70 .

Tabel 2. Hasil Angket motivasi Siswa Setelah belajar materi seleksi alam melalui model road benik

\begin{tabular}{ccccc}
\hline No & Rentangan $(\boldsymbol{\%})$ & Frekuensi & Ketuntasan $(\boldsymbol{\%})$ & Predikat \\
\hline 1 & $0-20$ & - & - & Kurang sekali \\
\hline 2 & $21-40$ & - & - & Kurang \\
\hline 3 & $41-60$ & 1 & $05,00 \%$ & Cukup \\
\hline 4 & $61-80$ & 13 & $70,00 \%$ & Baik \\
\hline 5 & $81-100$ & 6 & $30,00 \%$ & Sangat baik \\
\hline & Jumlah & 20 & $100 \%$ & \\
\hline
\end{tabular}

Dari tabel 2 tentang hasil angket respon siswa setelah belajar materi seleksi alam melalui model road benik dapat diketahui bahwa dari 20 siswa, jumlah siswa yang berpredikat cukup sebanyak 1 siswa dengan prosentase $05,00 \%$, berpredikat baik sebanyak 13 siswa dengan persentase
70,00\%. Sedangkan jumlah siswa yang berpredikat sangat baik sebanyak 6 siswa dengan persentase $30,00 \%$. Indikator ketercapai motivasi belajar dilihat melalui rentangan yaitu $61 \%-80 \%$, dengan predikat baik.

Tabel 3. Hasil Observasi Kreativitas Siswa Setelah pembelajaran dengan metode road benik

\begin{tabular}{ccccc} 
No & Rentangan $(\boldsymbol{\%})$ & Frekuensi & Ketuntasan $(\boldsymbol{\%})$ & Predikat \\
\hline 1 & $0-20$ & - & - & Sangat kurang \\
\hline 2 & $21-40$ & 3 & $15,00 \%$ & Kurang \\
\hline 3 & $41-60$ & 7 & $35,00 \%$ & Cukup \\
\hline 4 & $61-80$ & 10 & $50,00 \%$ & Baik \\
\hline 5 & $81-100$ & - & - & Sangat Baik \\
\hline & Jumlah & 20 & $100 \%$ & \\
\hline
\end{tabular}

Dari tabel 3 tentang hasil observasi kreativitas siswasetelah pembelajaran dengan model road benik pada siklus I dapat diketahui bahwa dari 20 siswa, jumlah siswa yang berpredikat kurang adalah 3 siswa dengan prosentase $15,00 \%$, siswa yang berpredikat cukup adalah 7 siswa dengan persentase $35,00 \%$. Sedangkan jumlah siswa yang mendapat predikat baik sebanyak 10 orang dengan persentase $50,00 \%$. Indikator ketercapai kreativitas belajar dilihat melalui rentangan yaitu $61 \%-80 \%$, dengan predikat baik

Tabel 4. Hasil kegiatan guru setelah proses belajar mengajar materi seleksi alam melalui model road benik

\begin{tabular}{ccccc}
\hline No & Rentangan (\%) & Bobot & Ketuntasan (\%) & Predikat \\
\hline 1 & $0-20$ & - & - & Sangat kurang \\
2 & $21-40$ & 2 & $03,8 \%$ & Kurang \\
3 & $41-60$ & 10 & $19,2 \%$ & Cukup \\
4 & $61-80$ & 15 & $28,8 \%$ & Baik \\
5 & $81-100$ & 4 & $07,6 \%$ & Sangat baik \\
\hline & Jumlah & 52 & $100 \%$ & \\
\hline
\end{tabular}


Dari tabel 4 tentang hasil observasi kegiatan gurusetelah pembelajaran dengan metode road benik pada siklus I dapat diketahui bahwa bobot ketercapaian kegiatan adalah 2 bobot kurang dengan prosentase 03,8\%, 10 bobot cukup dengan prosentase $19,2 \%, 15$ bobot baik dengan prosentase $28,8 \%, 4$ bobot sangat baik dengan prosentase $07,6 \%$, jadi jumlah bobot total yang diperoleh kegiatan guru pada siklus I adalah 31 dengan persentase 59,6\%. Indikator ketercapai kreativitas belajar dilihat melalui rentangan yaitu $61 \%-80 \%$, dengan predikat baik.

Adapun permasalahan yang muncul pada saat proses pembelajaran sebagai akibat tidak tercapainya ketuntasan hasil prestasi belajar siswa dan kreatifitas siswa serta kegiatan guru, diantaranya sebagai berikut:

a. Guru terlalu cepat dalam memberi penjelasan tentang teknik pelaksanaan model road benik sehingga siswa belum semuanya paham.

b. Guru kurang melibatkan anak secara total, perhatian hanya pada anak yang mendapat tugas berkompetisi saja, sehingga siswa yang lain merasa bebas tugas. c. Siswa masih belum paham dan mengerti tentang pelaksanaan model pembelajaran road benik sehingga terjadi beberapa anak salah mengambil kancing pada kotak temannya.

d. Dalam kegiatan terjadi kesalahan pengambilan kancing yaitu tidak di pungut satu persatu tetapi di caruk sehingga baru anak urutan pertama kancing sudah habis.

e. Anak laki-laki yang belum terlibat dalam kompetisi bersikap cuek dan hanya melihat dari jauh, sedangkan anak perempuan ngrumpi. Berdasarkan hasil refleksi dan untuk memperbaiki kekurangan-kekurangan pada siklus I, maka perlu adanya tindakan lanjutan untuk memperbaikinya pada siklus II.

\section{SIKLUS II}

Pada tahap observasi guru dan observer melakukan pengambilan data serta mengamati jalannya pembelajaran, sebagai berikut:

a. Hasil tes prestasi belajar setelah pembelajaran dengan model road benik.

\section{Tabel 5. Hasil prestasi belajar Setelah Pelaksanaan Pembelajaran Dengan Model Road} Benik.

\begin{tabular}{cccccc}
\hline No & SKBM & Kriteria & Frekuensi & Prosentase (\%) & Keterangan \\
\hline 1 & 70 & $\square 70$ & 3 & $15,00 \%$ & Belum tuntas \\
2 & & $\square 70$ & 17 & $85,00 \%$ & Tuntas \\
& & & 20 & $100 \%$ & \\
\hline \multicolumn{2}{c}{ Jumlah } & & &
\end{tabular}

Hasil Dari tabel 5 dapat diketahui bahwa dari 20 siswa, jumlah siswa yang belum tuntas belajar pada siklus II adalah 3 siswa dengan prosentase $15,00 \%$, sedangkan jumlah siswa yang tuntas sebanyak 17 siswa dengan persentase $85,00 \%$. Ketuntasan belajar siswa dilihat melalui SKBM yaitu yang mendapatkan nilai lebih dari atau sama dengan 70. Dengan demikian terjadi peningkatan yang cukup signifikan dari siklus I ke siklus II.

b. Hasil kreativitas siswa dalam pelaksanaan model pembelajaran road benik. 
Tabel 6. Hasil Observasi Kreativitas Siswa Setelah Pelaksanaan Pembelajaran Dengan Model Road Benik.

\begin{tabular}{|c|c|c|c|c|}
\hline & Rentangan (\%) & Frekuensi & Ketuntasan (\%) & Predikat \\
\hline 1 & $0-20$ & - & - & Sangat kurang \\
\hline 2 & $21-40$ & - & - & Kurang \\
\hline 3 & $41-60$ & 3 & $15,00 \%$ & Cukup \\
\hline 4 & $61-80$ & 16 & $80,00 \%$ & Baik \\
\hline 5 & $81-100$ & 3 & $05,00 \%$ & Sangat baik \\
\hline \multicolumn{2}{|r|}{ Jumlah } & 20 & $100 \%$ & \\
\hline
\end{tabular}

Dari tabel 6 dapat diketahui Hasil observasi pada siklus II diperoleh jumlah siswa yang berpredikat cukup adalah 3 siswa dengan persentase $15,00 \%$, sedangkan jumlah siswa yang mendapat predikat baik sebanyak 16 orang dengan persentase $80,00 \%$. Kemudian siswa yang mendapat predikat sangat baik sebanyak 3 orang dengan persentase $05,00 \%$. Dari hasil observasi kreativitas siswa mengalami peningkatan dari siklus I ke siklus II, hal ini menunjukkan bahwa siswa dapat melakukan kegiatan pembelajaran dengan model road benik dengan baik.

c. Hasil lembar observasi kegiatan guru setelah proses belajar mengajar materi seleksi alam melalui model road benik.

Tabel 7. Hasil kegiatan guru setelah proses belajar mengajar materi seleksi alam melalui model road benik

\begin{tabular}{ccccc}
\hline No & Rentangan (\%) & Bobot & Ketuntasan (\%) & Predikat \\
\hline 1 & $0-20$ & - & - & Sangat kurang \\
2 & $21-40$ & & & Kurang \\
3 & $41-60$ & 10 & $19,2 \%$ & Cukup \\
4 & $61-80$ & 30 & $57,69 \%$ & Baik \\
5 & $81-100$ & 3 & $05,76 \%$ & Sangat baik \\
\hline & Jumlah & 52 & $100 \%$ & \\
\hline
\end{tabular}

Dari tabel 7 tentang hasil observasi kegiatan gurusetelah pembelajaran dengan metode road benik pada siklus II dapat diketahui bahwa bobot ketercapaian kegiatan adalah 10 bobot cukup dengan prosentase 19,2\%, 30 bobot baik dengan prosentase $57,69 \%, 3$ bobot sangat baik dengan prosentase $05,76 \%$, jadi jumlah bobot total yang diperoleh kegiatan guru pada siklus II adalah 43 dengan persentase $82,6 \%$. Indikator ketercapai kreativitas belajar dilihat melalui rentangan yaitu $61 \%-80 \%$, dengan predikat baik.Sehingga pada siklus II hasil observasi kegiatan guru sudah melebihi dari indikator yang telah ditetapkan.

\section{KESIMPULAN}

Berdasarkan hasil penelitian, maka dapat disimpulkan bahwa penerapan model pembelajaran road benik dapat meningkatkan hasil belajar siswa. Hasil perolehan yang membuktikan hal tersebut adalah terjadinya peningkatkan hasil prestasi belajar siswa dari siklus I 70,00 \% ke siklus II 85,00 \% keberhasilan dalam motivasi siswa terhadap pembelajaran dengan model road benik $05,00 \%$ respon cukup, $65,00 \%$ respon baik, $30,00 \%$ respon sangat baik, Ini terlihat dari siswa sangat senang mengikuti pembelajaran dengan model road benik. Peningkatkan kreatifitas belajar siswa, dari siklus I 50,00\% 
ke siklus II 70,00\% dan peningkatan hasil kegiatan guru dari siklus I $28,80 \%$ ke siklus II $57,69 \%$.

\section{SARAN}

1. Dari hasil penelitian ini peneliti mengajukan beberapa saran sebagai berikut: Sekolah, dapat memfasilitasi kreativitas guru untukmenggunakan bahkan menciptakan metode-metode pembelajaran baru.

2. Guru, model pembelajaran "road benik" dapat dijadikan alternatif baru dalam menentukan pilihan model pembelajaran dalam pengajaran biologi disamping model pembelajaran-model pembelajaran lain. Karena sudah teruji dapat meningkatkan hasil prestasi siswa, motivasi belajar siswa, kreativitas siswa serta kegiatan belajar mengajar guru.

3. Siswa, untuk meningkatkan kreativitas seperti bermain, berkompetisi, melakukan pengumpulan data, menganalisis data dan menarik kesimpulan sehingga prestasi siswa dapat meningkat.

4. Untuk kelas yang baru pertama kali mengggunakan model pembelajaran road benik, guru sebaiknya menjelaskan terlebih dahulu teknis pelaksanaannya secara terperinci, agar siswa dapat mengerti dan faham apa yang harus dilakukan pada waktu kegiatan pembelajaran dengan meminimalkan kesalahan.

\section{DAFTAR RUJUKAN}

Anang Prasetyo. 2004. Sains SMP Kelas IX. Jakarta: Grasinda.

Tim MGMP IPA Magetan 2005.Ringkasan materi Ilmu Pengetahuan Alam Kelas IX. UD Tegal Arum

Arief S. Sardiman. 1992. Interaksi dan Motivasi Belajar Mengajar. Jakarta: PT Raja Grafindo Persada. . 2002. Media Pendidikan. Jakarta: PT Raja Grafindo Persada.

Azhar Arsyad. 2002. Media Pembelajaran. Jakarta: PT Raja Grafindo Persada.

Duffy, Thomas. M and Jonassen, David. H. 1992. Constructivism and the Technology of Instruction (A Conversation). New Jersey : Lawrence Erlbaum Assosiates Publisher.

Herman Hudojo. 1990. Strategi Mengajar Belajar Matematika. Malang: IKIP Malang.

Istamar Syamsuri. 2004. Sains Biologi SMP. Jakarta: PT Gelora Aksara Pratama.

Nasution. 1999. Kurikulun Dan Pengajaran. Jakarta: Bumi Aksara.

Ratna Willis Dahar. 1989. Teori-teori Belajar. Jakarta: Erlangga.

Roestiyah, N. K. 1991. Strategi Belajar Mengajar.Jakarta : Rineka Cipta

Runtut Prih Utami. 2006. Prestasi Belajar Biologi Pada Kompetensi Dasar Bioteknologi Menggunakan Model Pembelajaran Problem Based Instruction (PBI) Disertai Hand Out dan Model Pembelajaran Search Solve Create and Share (SSCS) Ditinjau Dari Intelegensi dan Kreativitas Siswa. Tesis Program Pasca Sarjana: UNS.

Slameto. 2002. Belajar dan Faktor-faktor Yang Mempengaruhinya. Jakarta: Bina Aksara.

Soeparno. 1988. Media Pengajaran Bahasa. Yogyakarta: PT Intan Pariwara. 